Women: A Cultural Review

\title{
Introduction: Imagining Motherhood in the Twenty-First Century-Images, Representations, Constructions
}

\section{Valerie Heffernan \& Gay Wilgus}

To cite this article: Valerie Heffernan \& Gay Wilgus (2018) Introduction: Imagining Motherhood in the Twenty-First Century - Images, Representations, Constructions, Women: A Cultural Review, 29:1, 1-18, DOI: $10.1080 / 09574042.2018 .1442603$

To link to this article: https://doi.org/10.1080/09574042.2018.1442603

\section{曲 Published online: 29 Mar 2018.}

Submit your article to this journal \lceil

Ш Article views: 660

Q View related articles $\sqsubset$

View Crossmark data $\asymp$

Citing articles: 1 View citing articles $₫$ 


\section{A L E E R I E}

\section{Introduction: Imagining Motherhood in the Twenty-First Century-Images, Representations, Constructions}

Abstract: This special issue of Women: A Cultural Review explores the diversity of maternal images proffered by various media formats, including cinema, literature and visual art, in the twenty-first century. The editors begin their introduction with an overview of recent research on maternal representation, then introduce the primary thematic concerns that feature in the included articles. They look at how mothers whose mothering experiences do not reflect conventional family models-particularly single mothers, LGBQ (lesbian, gay, bisexual, queer/questioning) mothers and migrant mothers -have been either sidelined by or misrepresented in cultural and media depictions of motherhood, and how these depictions have begun to evolve in recent years. They additionally explore bow the idealization of motherbood in mainstream culture casts women who choose not to have children in a negative light. Ultimately, they point to bow the images, representations and constructions of motherhood analysed by the various contributors both reflect and contribute to the shaping of contemporary cultural meanings of motherhood.

Keywords: art, film, literature, motherhood, mothers, popular culture 
This special issue of Women: A Cultural Revieze explores the diversity of maternal images that circulate in contemporary film, literature, the arts and popular culture, and analyses their engagement with and influence on the cultural meaning of motherhood in the twenty-first century. Indeed, this century seems particularly rife with media images and public performances of motherhood. As Elizabeth Podnieks and Rebecca Feasey have argued, images of mothers, mothering and motherhood are all-pervasive in television, cinema, magazines and the media, which has thrust motherhood centre stage in the public consciousness (Podnieks 2012; Feasey 2012). Not that this is anything new: from Norman Bates's hallucinations of his dead mother in Alfred Hitchcock's Psycho (1960) to Meryl Streep's heart-rending performance of motherhood in Alan Pakula's Sophie's Choice (1982), from Annie Leibovitz's controversial portrait of a heavily pregnant Demi Moore on the cover of Vanity Fair (Leibovitz 1991) to Martin Schoeller's more recent Time magazine cover of Los Angeles mum Jamie Lynne Grumet breastfeeding her three-year-old son (Schoeller 2012), and from Christina Crawford's contentious memoir of her abusive adoptive mother, Joan Crawford, in Mommie Dearest (1978) to Amy Chua's provocative depiction of her own mothering in her 'momoir', ${ }^{1}$ Battle Hymn of the Tiger Mother (2011), images, representations and constructions of mothers have shaped, and continue to shape, the way we imagine the institution of motherhood and the experience of mothering. Mindful of the fact that the images of motherhood that circulate in popular media, on television and in literature are not mere background noise to our daily lives, the contributions to this special issue of Women: A Cultural Revieze explore how images of maternity influence our understanding of what it means to be a mother, affect our expectations of motherhood and of mothers, frame our experience of mothering and even inform our reproductive decisions.

Feminists have long pointed to the power of discourses of the 'good mother' over women's practices of motherhood (Thurer 1994; Hays 1996; Ruddick 2001; Miller 2005; O’Reilly 2008; Goodwin and Huppatz 2010). Popular culture and the media are instrumental in propagating images of selfless mothers who sacrifice their time, energy, careers and even their individuality in the name of raising the next generation of 'good citizens'. Feasey underlines the old-fashioned ideologies at play in

1 Coined by the journalist Lizzie Skurnik, the term 'momoir' is often used to refer to a memoir about or written from the point of view of a mother (Skurnik 2006). these 'romanticised, idealised and indeed conservative images of selfless and satisfied "good" mothers who conform to the ideology of intensive mothering' (Feasey 2012: 3). Media representations of motherhood construct a moral landscape where certain choices and practices are deemed more appropriate than, and even morally superior to, others. Mothers whose experiences do not conform to the very narrow confines of these 
culturally sanctioned modes of motherhood-single mothers, migrant mothers, LGBQ (lesbian, gay, bisexual, queer/questioning) mothers, adoptive mothers and a whole host of other mothers-often struggle to relate their own experiences of mothering to the mainstream representations presented on television and in film, literature and magazines. It is for this reason that Sara Ruddick proclaims that the idealized figure of the Good Mother casts a long shadow on many actual mothers' lives' (Ruddick 2001: 189).

Moreover, media representations of motherhood are not just relevant to women who are mothers; they also have a profound impact on women who do not have children. As Katherine Kinnick underlines, culture and the media 'idealize and glamorize motherhood as the one path to fulfilment for women' (Kinnick 2009: 3), and women who cannot or who choose not to become mothers are often stereotyped as either 'desperate and unfulfilled' or 'selfish and deviant' (Letherby 2002: 10). Images of motherhood that circulate in popular culture thus function to regulate women's behaviour more generally.

In their insightful analysis of the idealization of motherhood in contemporary culture, Susan Douglas and Meredith Michaels argue that mediafuelled images of motherhood 'have laid down a thick, sedimented layer of guilt, fear, and anxiety as well as an increasingly powerful urge to talk back' (Douglas and Michaels 2004: 14). This special issue seeks to 'talk back' by pointing to some recent and powerful images of mothers and mothering that might give us pause for thought about the way we imagine motherhood in the twenty-first century. It explores how some contemporary writers, artists and film-makers eschew conventional and romanticized visions of blissful motherhood to shed light on the underbelly of contemporary motherhood-on women who struggle with, rail against or even reject entirely the maternal role. Finally, this special issue foregrounds representations of mothers whose experiences are not often the focus of attention and, in doing so, underscores the complexity of contemporary motherhood.

\section{Representations of Motherbood in the Trentieth Century}

In order to contextualize the efforts of this special issue's contributors to broaden and deepen understandings of how motherhood is framed in culture, we first present a sketch of the cultural backdrop against which they position their interpretations. While it is impossible to give comprehensive consideration to historical representations of motherhood in all of their various aspects, we attempt here to highlight some general trends 
in media and cultural depictions of mothers and motherhood in the twentieth and early twenty-first centuries. We focus on certain exemplary images that have played a role in shaping the public discourse on motherhood. These, we argue, have had a direct impact on mothers' lives. In painting an at least partial picture of how motherhood has been perceived and portrayed in the past, we lay the groundwork for this special issue's examination of how motherhood is imagined in contemporary contexts.

Models of mothering which have dominated the media world-in parenting magazines, on billboard advertisements, in prime-time soap operas and in blockbuster films-reveal a tendency towards the representation of a particular type of mother. These mothers are idealized, depicted almost exclusively as white, middle class, able-bodied, heterosexual and married; they are usually of the 'right' age (neither too old nor too young) and have the 'right' number of children (neither too few nor too many). Moreover, these 'perfect' mothers inevitably appear blissfully happy, to 'have it all together' and to love every moment of their motherhood. These homogenized, sanitized, media-fuelled images of motherhood bear little resemblance to the lived experiences of the majority of mothers. They set the stage for women who find themselves mothering in different social or familial contexts, whose experiences have not followed the idealized life paths presented by the media images, to feel somehow deficient or defective as mothers.

At the same time, some writers, artists, film-makers and television producers are beginning to engage more critically with conventional assumptions about motherhood. In the last few decades of the twentieth century in particular, we have seen the gradual emergence of a new body of work that offers a more nuanced view of mothers and motherhood. As the following overview shows, recent interest in alternative visions of motherhood is not confined to the fields of so-called 'high' art and literature; rather, it has begun to find expression in mainstream culture, Hollywood film and popular television as well. These more recent, unconventional images and narratives of mothers and mothering present promising possibilities for imagining motherhood in contemporary contexts.

\section{Single Mothers}

To begin with, it is important to underline that, by using the term 'single mothers', we in no way wish to suggest that the experiences of all mothers who are the sole carers for their children are homogenous. On the contrary, we recognize the myriad ways in which mothers can find themselves parenting alone, whether by dint of circumstance or by choice, as well as the multiple ways in which this can affect their mothering decisions and identities. We use the blanket term 'single mothers' here in full knowledge 
of its shortcomings, but as a means of pointing to the ways in which culture, the media and public discourse have tended to marginalize mothers whose family situations do not follow normative patterns and make sweeping assumptions about their experiences.

In fact, a look at how single mothers were represented by policymakers and in public discourse in the twentieth century reveals a moral hierarchy based on the circumstances through which these mothers came to be lone parents. Lisa Brush identifies a tendency in 'experts' discourse' literature towards classifying mothers 'according to their conformity with historically specific notions of proper womanhood' (Brush 1997: 720). She notes how in the early decades of the twentieth century, widows were more likely to be viewed favourably-and therefore considered worthy of state supportsince their circumstances reflected conservative notions of sexual respectability, maternal nurturance and good housekeeping (729). Women who were deserted by their husbands, by contrast, were often judged by their housewifely abilities; those whose cooking or cleaning skills were below par were considered partly to blame for their husbands' abandonment of them and thus less deserving of assistance (726). Mothers who had never been married were often assumed to be suffering from a physical or psychological defect, and this circumstance was even used to justify taking their children away from them (729).

Within the general group of single mothers, teen mothers were the subject of particularly negative attention in the mid twentieth century. Wanda Pillow finds that, at least since the 1960s, teen pregnancy has persistently been constructed as a problem requiring state and societal intervention. However, Pillow notes that changing social and political contexts led to different interpretations of 'what the problem of teen pregnancy is, who it is a problem for, and how government should intervene and on whose behalf (the teen mother, her child, or society)' (Pillow 2004: 18). Teen mothers were alternatively framed as the 'other girl' (33), whose irresponsibility and sexual promiscuity have led to welfare dependency and (deserved) social ostracization, or as the 'girl next door' (28), who made a mistake and is thus deserving of sympathy and help to get her life back on track. Pillow further points out how these competing discourses were often highly racialized, with white teen mothers more likely to be perceived as the 'girl next door' and black teen mothers more likely to be framed as the 'other girl'. As she points out, these two discursive frames are not actually very different; in both cases, teen motherhood is portrayed as a problem of epidemic proportions. Moreover, the discourse of epidemic serves as a justification for excessive levels of surveillance and control of younger mothers (38). 
Changes to the law in the United States and the United Kingdom in the late 1960s loosened restrictions on divorce and made it easier for couples to separate. Many other European countries liberalized their divorce laws over the course of the 1970s and early 1980s, including France (1975), Italy (1975), Germany (1977) and Spain (1981). These changes meant that the divorce rate began to rise and, from the 1970s onwards, divorced mothers became much more visible in many western countries. However, a conservative backlash against the trend towards liberalization, as well as against the perceived threat of feminism, meant that these women were often demonized in the conservative press as self-centred and neglectful, as 'conservatives accused divorced mothers of harming children in their selfish drives for fulfillment' (Brush 1997: 739). A tendency in more traditional newspapers to focus on poor single mothers around this time further reinforced associations between single motherhood and welfare dependency, and further denigrated divorced mothers.

By the end of the 1980s, the cultural arena finally began to reflect these alterations to social and familial structures, and there was an increase in the number of film and television depictions of single motherhood. Initially, these were rather tentative, light-hearted engagements with this new character type. For example, the popular Hollywood romantic comedy Baby Boom (Shyer 1987) focuses on career woman J. C. Wyatt (played by Diane Keaton), who 'inherits' a toddler from a deceased cousin and ultimately finds happiness in motherhood. However, it is worth noting here that the protagonist's ultimate happiness is linked to her newfound love interest, in the form of the local veterinary surgeon; thus, despite its initially innovative veneer, the film ultimately reinforces the heteronormative assumption that a single mother can only be truly happy when she finds a man.

In the 1980s and 1990s, the small screen was perhaps more successful in presenting novel family forms that came closer to reflecting the reality of many mothers' lives. The American sitcom Kate \& Allie (Coben 1984-9) focuses on two divorced women who opt to combine their households to support each other financially, practically and emotionally as they bring up their children. Vincent Stephens reads this unique kinship arrangement between Kate and Allie as groundbreaking, arguing that its innovative depiction of a female-headed household remains a benchmark for representing the intimate possibilities for "new women" in "our changing world"' (Stephens 2013: 905).

Murphy Brown (English 1988-98) was arguably more revolutionary in overturning the negative stereotype of the single mother, in that its eponymous protagonist, played by Candice Bergen, was a single mother by choice. Murphy Brown was heralded in feminist circles as a game-changer in the cultural representation of single motherhood. Jane Bock underlines 
the symbolic importance of the popular series: 'Murphy, as an upper-class, responsible, employed, home-owning woman, certainly met important criteria for effective parenting; thus she served as a model for other independent single women, symbolizing that they, too, could make responsible choices about motherhood' (Bock 2000: 64). However, and perhaps unsurprisingly, the conservative response to Murphy Brown was less enthusiastic. In a speech in May 1992, the US vice-president, Dan Quayle, caused notable controversy when he objected to the sitcom's undermining of the role of fathers in childrearing and to the erosion of American family values he perceived the series as promoting.

By the end of the 1990s and at the threshold of the twenty-first century, increasingly positive images of single motherhood had gained a firm foothold in popular culture and the media. The fact that some high-profile single celebrities-for example, Jodie Foster and Rosie O'Donnelldecided to have children, ${ }^{2}$ either through adoption or via sperm donor, contributed to the idea-and simultaneously to the concern in conservative circles-that, beyond conception, modern motherhood did not require the involvement of a father. Needless to say, the anxieties raised by this prospect were often played out in popular culture. For example, Angharad Valdivia points to negative portrayals of divorced or never-married mothers in Hollywood family films of the 1990s. Apart from defying the supposed conventions of 'good' motherhood by working outside the home, these mothers are depicted as being too focused on their own (sexual) desires, and their children inevitably suffer as a result. Valdivia observes only two exceptions to this rule-namely, Mrs Doubtfire (1993) and Forrest Gump (1994). In both cases, she finds that the depiction of the single mother breaks with the norm, in that both mothers work outside of the home but remain primarily focused on their children's well-being. As Valdivia notes, both films were box-office hits, suggesting that 'part of their success can be explained by their innovative approach to motherhood' (Valdivia 1998: 286).

In the early 2000s, a new television character was hailed as the poster child for single mothers: Lorelai Gilmore, from the popular Warner Bros. series The Gilmore Girls (Sherman-Palladino 2000-7). Lorelai, who disappointed her affluent, upper-class parents when she fell pregnant at the age of 16, manages to develop a successful career as the manager of a hotel, while maintaining a strong and communicative relationship with her academically gifted teenage daughter, Rory. Feasey notes that the show deliberately contrasts Lorelai's offbeat mothering with traditional notions of

2 Of note in this context is that both women later came out as gayO’Donnell in 2002 and Foster in 2013. 'good' motherhood, in particular through the more negative depiction of Lorelai's own mother, Emily Gilmore. Indeed, she suggests that, in some respects, The Gilmore Girls presents the fun-loving single mother as 'the more appropriate mother for the contemporary period' (Feasey 2012: 94). 


\section{$L G B Q$ Mothers}

LGBQ mothers were largely absent from cultural representations of mothers and mothering, and seldom figured in public discourse for most of the twentieth century. This began to change from the 1970s on, though change was slow in coming. Julie Thompson attributes this slow pace to the pervasive assumption that lesbianism and motherhood were mutually exclusive-'that "you can't be a mother if you're a lesbian" as well as the corollary "you're not really a lesbian if you have children"' (Thompson 2002: 2). Thompson describes how the mass media, legal discourse and feminist psychology shaped the contemporary meaning of the lesbian mother in the last three decades of the twentieth century. During this era, conservative media outlets tended to characterize lesbian mothers as a 'threat to traditional family values', whereas lesbian and gay publications swung between portraying lesbian mothers 'either as revolutionary feminists or as traitors to the feminist cause' (56).

Ellen Lewin describes how her groundbreaking study on lesbian motherhood was in part prompted by several high-profile court cases in the 1970s, in which mothers lost custody of their children on account of their homosexuality. In response, she felt a 'responsibility ... to demonstrate that lesbians were at least ordinary mothers, and therefore likely to be "as good as" heterosexual mothers in comparable social and economic circumstances' (Lewin 1993: 4). She points to a sea change in the way lesbian parenting was viewed between the time she began the research for her book in the mid 1970s and its publication in 1993. Lewin notes that, by the early 1990s, homosexuality had become much more socially acceptable, and lesbian mothers, while still not commonly depicted on television or in film, were at least 'less obscure' (2) than when she first started to study this marginalized group.

From the 1980s on, isolated examples of queer mothers began to make an appearance in popular culture and the media. Michaels credits the documentary film Choosing Children (1984), directed by Debra Chasnoff and Kim Klausner, with going some way towards normalizing the lesbian family, as well as presenting a positive narrative of assisted reproductive technologies (Michaels 1996: 56). Although this award-winning film was lauded in feminist circles and had an impact on the gay and lesbian community, there is little evidence that it had a significant effect beyond those circles.

A number of independent films released in the 1980s and 1990s hinted at lesbian motherhood. For example, Lianna portrays married mother-oftwo Lianna as she comes to terms with her homosexuality and attempts to create a new, independent life outside of her marriage (Sayles 1983). In a similar vein, the German drama film Aimée \& Jaguar depicts the real- 
life love story between Lilly Wust, a German mother of four children, and her German-Jewish lover Felice Schragenheim, during the Second World War (Färberböck 1999). In both of these cases, though, motherhood does not feature as a central topic but rather a background circumstance; the women in question become mothers before becoming aware of their homosexuality.

The French comedy film Gazon maudit, distributed in English as French Trwist (Balasko 1995), is arguably more radical in its intertwining of motherhood and lesbianism. The film tells the story of thirty-something motherof-two Loli's affair with lesbian Marijo. Significantly, Marijo also becomes a mother with the help of Loli's husband, Laurent, and the film closes with the three living together with their children. However, Kate Ince calls into question the potential import of the film's conclusion: 'The domestic situation shown in Gazon maudit is not realistically sustainable, and a kind of fantasy inheres in the fable-like conclusion to the film' (Ince 2002: 96). In sum, it does not seem as though filmic representations of LGBQ motherhood during this era contributed to the normalization or public acceptance of queer mothers.

By the end of the first decade of the twenty-first century, however, lesbian motherhood had begun to gain traction in film and television depictions of contemporary families. To mention one prominent example, the 2010 film The Kids Are Alright features a lesbian couple, Jules and Nic, played by Hollywood A-listers Julianne Moore and Annette Bening, who are bringing up two children, both conceived through a sperm donor (Cholodenko 2010). The film stands out as the first mainstream film to shine a light on lesbian parenting. At the same time, as Fiona Cox emphasizes, 'the overwhelming message coming from those involved with the production was that the film is not about lesbians but instead the importance of family' (Cox 2013: 254-5). Indeed, the popularity and commercial success of The Kids Are Alright suggests a growing public acceptance of diverse family forms in the twenty-first century.

\section{Migrant Mothers}

The massive movement of peoples between regions, countries and continents throughout the twentieth century-as a result of industrialization, urbanization, decolonization, the upheaval of war, and social and economic development, not to mention improvements to transportationmeant that migration became not just a facet of modern life, but also a phenomenon worthy of study. In recent years, feminist migration scholars such as Irene Gedalof have begun to point to gaps in the cultural narrative of migration and to argue that scholarly accounts of migration have tended to reaffirm a (male) plot of movement, dynamism and change, and to 
overlook the reproductive work done by women-and particularly mothers -in upholding cultural continuities in the face of migration:

We need to know how women construct migrant and transnational identities in the face of processes of displacement, non-belonging and isolation. But are we only hearing Odysseus' narrative of agency-still making the hero(ine) of migration narratives the uprooted, dislocated and solo actor remaking her identity in a new world? What about a migrant Penelope's story of emplacement, belonging and connectedness? Can we unpick the complexities of her small stories to reveal another site in which identities are made? (Gedalof 2009: 97)

Against this convention, Gedalof draws attention to migrant women's, and particularly migrant mothers', practices of cultural reproduction-on how they pass on the language, culture and heritage of their homeland to their children as a means of reaffirming their identity and a sense of belonging.

A photograph from 1936 by documentary photographer Dorothea Lange, which became known as 'Migrant Mother', came to represent, as James Curtis notes, 'a timeless and universal symbol of suffering in the light of adversity' (Curtis 1986: 1). Lange's photograph, one of a series of six that she took, ${ }^{3}$ depicts 32-year-old migrant farm worker Florence Owens Thompson-though Lange did not record her name-with three of her seven children. Lange came across the migrant mother at a pea pickers' camp in Nipomo, California, one rainy afternoon in March 1936. As Curtis argues, Lange's decision to emphasize the number of children in the caption of the photograph 'was undoubtedly influenced by prevailing cultural biases', as 'a family of seven children exceeded contemporary social norms' (5). There is also evidence to suggest that one of Lange's series, which depicts the migrant mother breastfeeding her child, was staged to evoke associations with the Virgin Mary; indeed, as Curtis notes, Lange's 'Migrant Mother' has alternatively been referred to as 'Migrant Madonna' (9).

Nonetheless, it is the final photograph in the series, published shortly after the photographer's return to San Francisco, which has become iconic. Its sympathetic portrayal of the hunger and hardship of a hardworking family prompted the dispatch of government relief to the migrant camps in Nipomo. Its longer-term impact has focused on its aesthetic value as a masterpiece of American documentary photography and as 'a powerful but anonymous symbol of the sufferings and fortitude engendered by the Great Depression' (20).

3 Curtis notes that Lange did not include the sixth image in her series (Curtis 1986: 6).
If migrant mothers are notably absent from popular culture for most of the twentieth century, they play a strong role in the literature of immigrant 
communities living in the United States, the United Kingdom and France that began to emerge in the course of this century. This body of literature, as well as that penned by their children, offers many rich examples of migrant mothering. Chicano and Chicana writers in the United States, including Sandra Cisneros, Ana Castillo and Denise Chávez, have been prolific, offering renditions of mothers who loom large in their daughters' lives. These mothers are often portrayed as holding their daughters back from fully integrating into their new cultures, owing to the mothers' insistence on maintaining their cultural ties to Mexico. Conflictual mother-daughter relationships also feature in British and French literature by women writers of Caribbean descent. In this literature, mothers often figure heavily in upholding the culture and traditions of the home country (or mother country).

Audre Lorde's autobiographical novel Zami: A Nerw Spelling of My Name (1982) provides a much lauded example of a twentieth-century American depiction of a migrant mother who fits this mould. Lorde places the protagonist's conflicted relationship with her mother, Linda, an immigrant from Grenada, at the centre of her ruminations. Linda's relationship to her homeland is framed in resolutely maternal terms, and her determination to pass on this sense of belonging to her daughters is in part successful; on a visit to Grenada, the protagonist Audre is struck by the power of her own cultural and emotional bond to the place: 'I saw the root of my mother's powers walking through the streets. I thought, this is the country of my foremothers, my forebearing mothers, those Black island women who defined themselves by what they did' (Lorde 1982: 9). At the same time, Linda's authoritarian mothering is presented as an impediment to her daughter's development as an individual and a sexual subject. Paradoxically, as Bethany Jacobs argues, it is only through accepting the maternal potential of her subjectivity and sexuality that Audre emerges as 'a product of her mother with her own story to tell' (Jacobs 2015: 126).

Lorde's depiction of her Grenadian mother reflects a common trope in literature about migrant mothers, and indeed about mothers in literature more generally. As Marianne Hirsch persuasively argues, mothers have long been portrayed from the point of view of their daughters-a formula she views as highly problematic: 'To speak for the mother, as many daughters ... do, is at once to give voice to her discourse and to silence and marginalize her' (Hirsch 1989: 16). In order for women's writing to represent the full range of female (and maternal) experiences, Hirsch contends, mothers must be allowed a voice in discourse. We might similarly argue that literature and culture will not be able to comprehend the diversity of migrant women's experiences unless we make way for-and shed light on-those images and narratives that tell migrant women's stories in their own words and from their own point of view. 


\section{Childless and Child-Free Women}

Much has been made of recent figures relating to high rates of childlessness in Europe and North America. At the same time, recent longitudinal studies acknowledge that childlessness is not a new phenomenon. Michaela Kreyenfeld and Dirk Konietzka point to evidence that approximately 20 per cent of European women born at the beginning of the twentieth century remained childless; this compares with figures of 25 per cent for women in the United States and 30 per cent for Australian women who were born in the same time period (Kreyenfeld and Konietzka 2017: 5). The rise in marriage and fertility rates in the 1950s and 1960s-and the corresponding drop in the number of childless women around this time-was thus an exception rather than the rule.

At the same time, the social and cultural backdrop for women today who are child-free or childless is quite different from that which framed women's experiences a century ago. As Éva Beaujouan et al. (2017) point out, childlessness in the early decades of the twentieth century was closely correlated with non-marriage and with specific historical circumstances that hindered women from having children. For example, the deaths of many young men in the First World War meant that many women did not find a partner with whom to start a family, and the economic instability of the 1920s further exacerbated the shift away from marriage and children. By contrast, the current increase in childlessness evident in many western countries is more closely related to social, economic and cultural trends which have emerged over the last half-century and which, according to Tomáš Sobotka, 'appear to steer women away from having children' (Sobotka 2017: 17). Increased access to contraception, the expansion of educational opportunities for women and an upsurge in female participation in the workforce since the 1970s have contributed to women delaying motherhood or rejecting it altogether. Moreover, cultural shifts such as 'the rise of individualism, the desire for selffulfilment and the more tolerant attitudes towards non-traditional living arrangements' also play a part in causing women to think twice about motherhood (Beaujouan et al. 2017: 2).

The twentieth century thus saw a cultural shift away from an understanding of motherhood as a social expectation, a 'civic duty' (Plant 2010: 77) or a 'calling' (Vinken 2001: 7), towards its conception as a lifestyle choice. Involuntary childlessness continues to cause great hardship and pain for women who are prevented by circumstances beyond their control from having children. At the same time, the terms 'voluntary childlessness', 'childless by choice' and 'child-free' have emerged since the 1970s as counterdiscourses to the traditional narrative of childlessness. 
In 1971, the American activist Ellen Peck published a popular book entitled The Baby Trap, in which she defended her own decision not to have children and rationalized the growing interest in a child-free life. Peck's impassioned appeal calls into question the assumption that children bring great personal happiness; however, its reliance on conventional notions of feminine beauty and wifely duty arguably undermines its feminist potential:

I want to tell you about this trap, not because I see babies as the enemies of the human race, really, but because I see babies as the enemies of you. ... The people who set the trap never tell you that if you're not real careful you'll be cheated out of fifteen years of young life and intense experiences that can never be yours again. I don't want you to wake up a dozen years from now and realize that your days are built on routine, that your life consists of living vicariously through your children, that you've lost your zest for new experiences-and quite possibly your husband's interest as well. (Peck 1971: 20-1)

Despite its shortcomings, Peck's book was revolutionary in disputing the conventional equation of motherhood with womanhood. It paved the way for a number of academic studies in the 1970s and 1980s that delved deeper into the cultural pressure on women (and couples) to have children and the stigmatization of child-free identities (for example, Russo 1976, 1979; Houseknecht 1978, 1982; Veevers 1980). Peck also went on to form the National Organization for Non-Parents in 1972, a group that sought to promote awareness about pronatalism and intentional childlessness.

Irene Reti's Childless by Choice: A Feminist Anthology (1992) was hailed by many as groundbreaking in that it brought together a collection of essays, short stories and poems by women from diverse ethnic backgrounds, social classes and generations that tell their own unique stories of voluntary childlessness. As Reti points out in her introduction, women who choose not to have children 'live in the negative, in the absence, always on the defensive' (Reti 1992: 1). The women whose voices are represented in the anthology offer many different explanations for their decisions to live child-free, but they all present their choices as positive and life-affirming.

For many women not inclined towards motherhood, Reti's volume was a breath of fresh air. Despite this, it did little to shake the inviolable assumption that motherhood, if not the only lifestyle choice available to women, was still the right choice. Indeed, Douglas and Michaels, surveying the cultural landscape at the beginning of the twenty-first century, reaffirm the pervasiveness of this notion: 'The only truly enlightened choice to make as a 
woman, the one that proves, first, that you are a "real" woman, and second, that you are a decent, worthy one, is to become a "mom"' (Douglas and Michaels 2004: 5).

\section{Imagining Motberbood in the Twenty-First Century}

This special issue offers an exploration of an array of complex and, at times, provocative depictions of mothers and the maternal experience that unsettle and dismantle the picture-perfect images of motherhood that are all too often presented in the mainstream media. By looking at 'other-thanperfect' mothers and alternative experiences of mothering, the various contributions challenge twenty-first-century understandings of motherhood. They present and critique a variety of portrayals of motherhood in contemporary art, literature, television, film, and public and social discourse. The contributors offer a breadth of images of mothers and mothering thatboth individually and collectively-depart from and call into question normative constructions of motherhood in important ways.

Certain contributions shine a light on the experiences of women who, for one reason or another, find themselves excluded from mainstream discourse or mothering on the margins. In this vein, Penelope Mendonça sketches a picture-in the most literal sense-of the difficulties faced by single mothers who struggle to construct narratives that explain the absence of the fathers of their children. Egle Kačkute considers the ambiguous position of migrant mothers who endeavour to bring up their children in a culture that is foreign to them-and which, in turn, views these mothers and their children as foreign. And Elizabeth Reed discusses the different ways the LGBQ mothers she interviewed relate their queer identities with conventional cultural images of motherhood, and she considers the role of popular culture and the media in allowing these LGBQ women to construct alternative maternal narratives and images to describe their choices and practices.

Other contributions extend the complex emotional landscape of motherhood, calling attention to some of the more negative feelings it evokes-ambivalence, resentment and even murderous rage. Although Adrienne Rich highlighted such feelings in her groundbreaking study Of Woman Born (1976), there remains a persistent tendency for these to be downplayed in popular representations of mothering. Some of our contributors destabilize the assumption that motherhood is categorically linked to unconditional love through exploring the negative emotions evoked by the experience of mothering and of being mothered. Charged relationships between mothers and daughters loom large in these explorations. Katrin 
Wehling-Giorgi analyses how contemporary writers Alice Sebold and Elena Ferrante depict mothers who defy the cultural and social norms we associate with motherhood; the mothers they represent are often selfish, regretful, remote, indifferent, or jealously controlling when it comes to their daughters. Valerie Heffernan's interview with Sarah Strong delves into the artist's tense relationship with her mother, the Irish poet Eithne Strong (1923-99), and probes the impact that this had on her artistic practice. As this interview reveals, the powerful maternal focus of Strong's art emerges as another medium for constructing alternative images of the maternal, and for imagining motherhood in innovative ways.

Berit Åström and Julie Rodgers take a slightly different tack as they explore how conventional concepts of mothers and motherhood affect those who are not mothers. Rodgers confronts the problems that arise from the definitive intertwining of womanhood with motherhood, and from the pervasive assumption that all women should want to become mothers. She elucidates how, against this pronatalist backdrop, contemporary cultural media frequently belittle and denigrate women who choose not to have children. Åström looks at emerging and increasingly positive images of 'new' fatherhood, demonstrating how this trope sometimes comes at the expense-and even the annihilation-of positive images of motherhood. Taken together, Åström's and Rodgers's articles reveal the extent to which contemporary cultural expectations of mothers and visions of the maternal role have a pervasive effect on our expectations of mothers and fathers, of men and women.

All but one of the contributions to this special issue emerged from an international, interdisciplinary conference on the topic of 'Motherhood and Culture', held at Maynooth University in Ireland, in June 2015. ${ }^{4}$ This conference sought to analyse the cultural meaning of motherhood in the contemporary era-understood in its broadest sense to include adoptive, foster, surrogate, LGBT (lesbian, gay, bisexual, transgender) and other mothering-through exploring the stories we tell ourselves about mothers, mothering and motherhood through history, across diverse media, and from various cultural, national, racial, class and gendered perspectives. The articles included here highlight some of the stories that run counter to conventional narratives about mothers and mothering, and invite us to

4 Åström's contribution to this special issue is included because it reflects on how literary and cultural representations of motherhood also affect the portrayal of fathers.

\section{Disclosure Statement}

No potential conflict of interest was reported by the authors. 


\section{Funding}

The research for this article was funded by an Irish Research Council Starter Research Project Grant [strand RPG2013-1].

\section{ORCID}

Valerie Heffernan (1) http://orcid.org/0000-0002-9960-8213

Gay Wilgus (1) http://orcid.org/0000-0003-3097-735X

\section{Works Cited}

Balasko, Josiane (dir.) (1995), Gazon maudit, Paris: AMLF.

Beaujouan, Éva, Tomáš Sobotka, Zuzanna Brzozowska and Kryštof Zeman (2017), 'Has Childlessness Peaked in Europe?', Population and Societies 540, at www. ined.fr/fichier/s_rubrique/26128/540.population.societies.2017.january.en. pdf (accessed 18 December 2017).

Bock, Jane D. (2000), 'Doing the Right Thing? Single Mothers by Choice and the Struggle for Legitimacy', Gender and Society 14:1, pp. 62-86.

Brush, Lisa D. (1997), 'Worthy Widows, Welfare Cheats: Proper Womanhood in Expert Needs Talk about Single Mothers in the United States, 1900 to 1988', Gender and Society 11:6, pp. 720-46.

Chasnoff, Debra and Kim Klausner (dir.) (1984), Choosing Children, Columbus, $\mathrm{OH}$ : New Day Films.

Cholodenko, Lisa (dir.) (2010), The Kids Are Alright, Los Angeles, CA: Gilbert Films.

Chua, Amy (2011), Battle Hymn of the Tiger Mother, New York: Penguin.

Coben, Sherry (1984-9), Kate \& Allie, Los Angeles, CA: Alan Landsburg, Mort Lachman and Reeves Entertainment Group.

Cox, Fiona (2013), 'Fab Lesbianism and Family Values: Costuming of Lesbian Identities in The L Word and The Kids Are Alright, in Stella Bruzzi and Pamela Church Gibson (eds), Fashion Cultures Revisited: Theories, Explorations and Analysis, London: Routledge, pp. 249-60.

Crawford, Christina (1978), Mommie Dearest, New York: William Morrow.

Curtis, James C. (1986), 'Dorothea Lange, Migrant Mother, and the Culture of the Great Depression', Winterthur Portfolio 21:1, pp. 1-20.

Douglas, Susan J. and Meredith W. Michaels (2004), The Mommy Myth: The Idealization of Motherbood and How It Has Undermined All Women, New York: Free Press.

English, Diane (1988-98), Murphy Brown, Los Angeles, CA: Shukovsky English Entertainment and Warner Bros. Television.

Feasey, Rebecca (2012), From Happy Homemaker to Desperate Housewives: Motherhood and Popular Television, London: Anthem Press. 
Färberböck, Max (dir.) (1999), Aimée \& Jaguar, Berlin: Senator Film.

Gedalof, Irene (2009), 'Birth, Belonging, and Migrant Mothers: Narratives of Reproduction in Feminist Migration Studies', Feminist Revierw 93:1, pp. 81-100.

Goodwin, Susan and Kate Huppatz (eds) (2010), The Good Mother: Contemporary Motherboods in Australia, Sydney: Sydney University Press.

Hays, Sharon (1996), The Cultural Contradictions of Motherhood, New Haven, CT: Yale University Press.

Hirsch, Marianne (1989), The Mother/Daughter Plot. Narrative, Psychoanalysis, Feminism, Bloomington: Indiana U.P.

Hitchcock, Alfred (dir.) (1960), Psycho [motion picture], Los Angeles, CA: Shamley Productions.

Houseknecht, Sharon K. (1978), 'Voluntary Childlessness: A Social Psychological Model', Alternative Lifestyles 1:3, pp. 379-402.

- (1982), 'Voluntary Childlessness: Toward a Theoretical Integration', Journal of Family Issues 3:4, pp. 459-71.

Ince, Kate (2002), 'Queering the Family? Fantasy and the Performance of Sexuality and Gay Relations in French Cinema 1995-2000', Studies in French Cinema 2:2, pp. 90-7.

Jacobs, Bethany (2015), 'Mothering Herself: Manifesto of the Erotic Mother in Audre Lorde's Zami: A New Spelling of My Name', MELUS 40:4, pp. 110-28.

Kinnick, Katherine (2009), 'Media Morality Tales and the Politics of Motherhood', in Ann C. Hall and Mardia J. Bishop (eds), Mommy Angst: Motherhood in American Popular Culture, Santa Barbara, CA: Praeger/ABC-CLIO, pp. 1-28.

Kreyenfeld, Michaela and Dirk Konietzka (2017), 'Analysing Childlessness', in Michaela Kreyenfeld and Dirk Konietzka (eds), Childlessness in Europe: Contexts, Causes, and Consequences, Dordrecht: Springer, pp. 3-15.

Leibovitz, Annie (1991), Cover Image, Vanity Fair, August, at www.vanityfair.com/ news/2011/08/demi-moore-201108 (accessed 28 November 2017).

Letherby, Gayle (2002), 'Childless and Bereft? Stereotypes and Realities in Relation to Voluntary and Involuntary Childlessness and Womanhood', Sociological Inquiry 72:1, pp. 7-20.

Lewin, Ellen (1993), Lesbian Mothers: Accounts of Gender in American Culture, Ithaca: Cornell University Press.

Lorde, Audre (1982), Zami: A New Spelling of My Name, Freedom, CA: Crossing Press.

Michaels, Meredith W. (1996), 'Other Mothers: Towards an Ethics of Postmaternal Practice', Hypatia 11:2, pp. 49-70.

Miller, Tina (2005), Making Sense of Motherhood: A Narrative Approach, Cambridge: Cambridge University Press.

O’Reilly, Andrea (ed.) (2008), Feminist Mothering, Albany: State University of New York Press.

Pakula, Alan (dir.) (1982), Sophie’s Choice, Los Angeles, CA: Universal Pictures.

Peck, Ellen (1971), The Baby Trap, New York: Pinnacle Books.

Pillow, Wanda S. (2004), Unfit Subjects: Education Policy and the Teen Mother, 19722002, New York: Psychology Press. 
Plant, Rebecca Jo (2010), Mom: The Transformation of Motherhood in Modern America, Chicago, IL: University of Chicago Press.

Podnieks, Elizabeth (ed.) (2012), Mediating Moms: Mothers in Popular Culture, Montreal: McGill-Queen's University Press.

Reti, Irene (1992), Childless by Choice: A Feminist Anthology, Santa Cruz, CA: HerBooks.

Rich, Adrienne (1976), Of Woman Born: Motherhood as Experience and Institution, New York: Norton.

Ruddick, Sara (2001), 'Talking about "Mothers", in Moyra Davey (ed.), Mother Reader: Essential Writings on Motherhood, New York: Seven Stories, pp. 187-98.

Russo, Nancy Felipe (1976), 'The Motherhood Mandate', Journal of Social Issues 32:3, pp. 143-53.

- (1979), 'Overview: Sex Roles, Fertility and the Motherhood Mandate', Psychology of Women Quarterly 4:1, pp. 7-15.

Sayles, John (dir.) (1983), Lianna, Los Angeles, CA: United Artists.

Schoeller, Martin (2012), Cover Image, Time, 10 May, at http://time.com/ 3450144/behind-the-cover-are-you-mom-enough/ (accessed 14 December 2017).

Sherman-Palladino, Amy (2000-7), The Gilmore Girls, Burbank, CA: Warner Bros. Shyer, Charles (dir.) (1987), Baby Boom, Los Angeles, CA: United Artists.

Skurnik, Lizzie (2006), 'Chick Lit, the Sequel: Yummy Mummy', New York Times, 17 December.

Sobotka, Tomáš (2017), 'Childlessness in Europe: Reconstructing Long-Term Trends among Women Born in 1900-1972', in Michaela Kreyenfeld and Dirk Konietzka (eds), Childlessness in Europe: Contexts, Causes, and Consequences, Dordrecht: Springer, pp. 17-53.

Stephens, Vincent (2013), 'Odd Family Out: Closely Reading Kate \& Allie's "New Women” Household', Journal of Popular Culture 46:4, pp. 886-908.

Thompson, Julie M. (2002), Mommy Queerest: Contemporary Rhetorics of Lesbian Maternal Identity, Amherst: University of Massachusetts Press.

Thurer, Shari L. (1994), The Myths of Motherhood: How Culture Reinvents the Good Mother, New York: Houghton Miffin.

Valdivia, Angharad N. (1998), 'Clueless in Hollywood: Single Moms in Contemporary Family Movies', Journal of Communication Inquiry 22:3, pp. 272-92.

Veevers, Jean E. (1980), Childless by Choice, Toronto: Butterworths.

Vinken, Barbara (2001), Die deutsche Mutter: der lange Schatten eines Mythos, Munich: Piper. 